\title{
Kemampuan Pemodelan Matematis dalam Menyelesaikan Soal Matematika Kontekstual
}

\author{
Hikmatul Khusna ${ }^{*}$, dan Syafika Ulfah ${ }^{2}$ \\ $1^{*}, 2$ Program Studi Pendidikan Matematika, Universitas Muhammadiyah Prof Dr Hamka \\ Jalan Tanah Merdeka, Kp. Rambutan, Jakarta, Indonesia \\ 1*hikmatulhusna@uhamka.ac.id, 2syafika.ulfah@uhamka.ac.id
}

Artikel diterima: 17-09-2020, direvisi: 27-01-2021, diterbitkan: 31-01-2021

\begin{abstract}
Abstrak
Kemampuan guru menghadirkan soal-soal yang memiliki konteks kehidupan sehari-hari sangat dibutuhkan dalam kelas. Penelitian ini bertujuan untuk mendeskripsikan dan menganalisis kemampuan pemodelan matematis siswa dalam menyelesaikan soal matematika kontekstual. Penelitan ini dirasa penting untuk dikaji karena tuntutan pembelajaran yang mengharuskan siswa tidak hanya pandai berhitung tetapi dapat mengaplikasikan matematika dalam kehidupan, sehingga kemampuan pemodelan matematika sebagai jembatan antara masalah matematika dan masalah nyata dirasa penting untuk dimiliki oleh siswa. Subjek penelitian diberikan instrumen berupa soal matematika kontekstual, kemudian peneliti menganalisis hasil kerja subjek serta melakukan wawancara subjek terkait hasil pengerjaan instrumen tersebut. Dari hasil penelitian ini disimpulkan bahwa kemampuan pemodelan matematis siswa beragam, tidak bergantung pada kemampuan matematika siswa tinggi, sedang, rendah; masih ada siswa yang tidak membuat pemodelan matematis karena tidak memahami soal yang diberikan; pemodelan gambar yang dibuat oleh siswa beragam namun sebagian besar masih kurang tepat dalam membuat pemodelan gambar sesuai dengan permasalahan yang diberikan; kemampuan siswa dalam membuat pemodelan matematis sebagian besar masih kurang.

Kata Kunci: kemampuan pemodelan matematis, matematika kontekstual
\end{abstract}

\section{Mathematical Modeling Ability in Solving Contextual Mathematical Problems}

\begin{abstract}
The teacher's ability to present questions that have the context of everyday life is needed in the classroom. This study aims to describe and analyze students' mathematical modeling abilities in solving contextual math problems. This research is considered important to study because the demands of learning require students not only to be good at arithmetic but also to be able to apply mathematics in life, the ability of mathematical modeling as a bridge between mathematical problems and real problems is considered important for students to have. The research subject was given an instrument in the form of a contextual math problem, then the researcher analyzed the subject's work and conducted subject interviews related to the results of working on the instrument. The results is mathematical modeling abilities of students varied, it did not depend on high, medium, low students' mathematical abilities; There are still students who do not make mathematical modeling because they dont understand the questions given; the forms of image modeling made by students are still diverse but most of them are still inaccurate in making image modeling according to the problems give and making mathematical modeling is still lacking.

Keywords: Mathematical Modeling Ability, Contextual Mathematical
\end{abstract}




\section{Pendahuluan}

Matematika tidak dapat dipisahkan dalam kehidupan (Hernawati, 2012), karena hadirnya matematika merupakan alat untuk memudahkan kehidupan manusia (Nanang, 2012; Rachma, Setyadi, \& Mampouw, 2020). Oleh karena itu, matematika dihadirkan dalam setiap jenjang sekolah untuk melatih siswa dalam mencari masalah, memecahkan masalah, serta menggunakan matematika dalam menyelesaikan masalah (Puspitasari, 2012; Sinaga, Zulkardi, \& Yusup, 2016). Sehingga dalam belajar matematika tidak hanya belajar menghitung, tetapi melatih siswa agar dapat mengembangkan kemampuan berpikir logis, analitis, sistematis, kritis, dan kreatif (Afriansyah, dkk., 2020)). Kemampuan-kemampuan tersebut diharapkan dapat diaplikasikan oleh siswa dalam kehidupan sehingga hasil dari belajar matematika di sekolah lebih dari sekedar belajar menghitung. Hal ini karena tuntutan dalam pembelajaran matematika adalah siswa dapat menyelesaikan masalah nyata dalam matematika (Nuryadi dkk., 2018). Masalah nyata yang dimaksudkan tidak mengacu pada realitas tetapi pada sesuatu yang dapat dibayangkan oleh siswa (Slettenhaar dalam Dwiwansyah Musa, 2017). Dengan belajar matematika, diharapkan siswa mampu menerapkan matematika untuk menyelesaikan masalah nyata maupun masalah manipulatif.

Kemampuan guru menghadirkan soalsoal yang memiliki konteks kehidupan sehari-hari sangat dibutuhkan dalam kelas (Herawati \& Nurhayati, 2019; Agnesti \& Amelia, 2020). Hal ini karena tantangan di abad 21 mengharuskan matematika yang diajarkan di sekolah memiliki korelasi dengan dunia nyata (Karabork \& Durmus, 2020). Tetapi kebanyakan siswa mengalami kesulitan dalam mengaplikasikan matematika ke dalam situasi kehidupan nyata (Jenning \& Dunne dalam Rahmawati, 2013).

Hal ini diakibatkan karena pembelajaran yang tidak melibatkan kehidupan nyata menjadikan matematika kurang bermakna. Padahal pembelajaran yang bermakna akan memotivasi siswa dalam belajar karena siswa memperoleh pengalaman dan pengetahuan dari lingkungan (Lisnani, 2019). Menurut Van de Heuvel-Panhuizen (Nuryadi, 2014), jika siswa belajar matematika terpisah dengan pengalaman mereka sehari-hari, maka siswa akan cepat lupa dan tidak dapat mengaplikasikan matematika. Pembelajaran yang melibatkan pengalaman siswa akan meningkatkan motivasi siswa dalam belajar (Sari \& Afriansyah, 2020). Learning mathematics would be more fun if the student is active in connecting between a real phenomenon with an understanding that would be obtained student math (Supriadi dkk., 2014). Owens (Sumarmo dkk., 2012) menambahkan bahwa pengajaran konteksual secara praktis menjanjikan peningkatan minat, ketertarikan belajar siswa dari berbagai latar belakang serta 
meningkatkan partisipasi siswa dengan mendorong secara aktif dalam memberikan kesempatan kepada mereka untuk mengkoneksikan dan mengaplikasikan pengetahuan yang telah mereka peroleh (Rachma, Setyadi, \& Mampouw, 2020). Dengan menempatkan realitas dan pengalaman siswa dalam pembelajaran diharapkan dapat memudahkan siswa dalam membangun pemahaman mereka sendiri terhadap konsep dan pengetahuan matematika (Fauzi \& Susilo, 2017).

Masalah kontekstual adalah masalah yang sesuai dengan situasi yang dialami siswa, sesuai dengan kehidupan nyata dan dekat dengan siswa (Afriansyah, 2015; Rizki, 2018). Masalah kontekstual mengajarkan siswa mengkonstruksikan masalah tertentu, melihat sebuah masalah dalam kaca mata umum kemudian digunakan sebagai cara konkrit merepresentasikan situasi baru dan penyelesaian atas kasus tersebut (Rahayu, 2012; Yanuarto dkk., 2014). Sedangkan De Lange (Edo \& Tasik, 2019) menyatakan bahwa definisi dari dunia nyata sebagai suatu dunia nyata yang kongkrit, yang disampaikan kepada siswa melalui aplikasi matematika.

Menurut Amala \& Ekawati (2016), terdapat dua macam matematisasi, yaitu matematisasi horizontal dan matematisasi vertikal. Matematisasi horizontal merupakan proses mengubah masalah dunia nyata ke dalam simbol-simbol matematika. Sedangkan matematisasi vertikal adalah proses yang terjadi di dalam sistem matematika itu sendiri. Proses perpindahan dari dunia nyata ke dunia simbol merupakan ranah dalam membuat model matematika (Afriansyah, 2013). Pemodelan merupakan komponen pembelajaran kontekstual. Model matematis merupakan jembatan dalam menyelesaikan masalah matematika dalam dunia nyata (Brinus, Makur, \& Nendi, 2019). Menurut Abram dalam (Pitriani, 2016) model matematis merepresentasikan suatu situasi secara simbolik, secara grafik, dan atau secara numerik untuk menguatkan suatu aspek yang pokok dan untuk dipelajari dengan mengenyampingkan hal-hal yang kurang penting. Menurut Tata (2013) pemodelan matematis (mathematical modeling) mempunyai arti yang berbeda dengan model matematis, pemodelan merujuk pada suatu proses terbentuknya model matematis (Suharyono \& Rosnawati, 2020), sedangkan model matematis adalah produk atau hasil dari pemodelan matematis yang merupakan representasi abstrak yang berbentuk simbol, persamaan, grafik, tabel, diagram, maupun gambar matematika atau yang lainnya yang merupakan representasi matematis dari permasalahan di luar matematika (Muzaki \& Masjudin, 2019). Penggunaan pemodelan matematik akan memberikan kemudahan bagi siswa untuk menyelesaikan soal-soal cerita matematika, karena pemodelan matematik ini sesuai dengan cara berpikir 
siswa yang konkret-semikonkret, enaktifikonik atau konkret-piktoria (Nursyarifah dkk., 2017).

Kemampuan pemodelan matematis menurut Blum dan Kaiser (Supriadi dkk., 2014) terdiri dari Structuring, mathematization, Solving, Interpreting, dan validating. Pada tahap structuring, siswa melakukan identifikasi terhadap masalah nyata. Tahap mathematization, siswa mengubah masalah nyata yang telah di identifikasi ke dalam bentuk matematika. Tahap solving, siswa melakukan penyelesaian masalah matematika dengan cara matematika. Interpreting yaitu mengubah solusi matematika yang diperoleh menjadi solusi dalam masalah nyata. Validating, yaitu tahap mengecek ulang jawaban yang telah ditemukan oleh siswa.

Penelitian yang berkaitan dengan matematika kontekstual telah dilakukan oleh Dahlan dan Juandi (2011). Penelitian ini meneliti tentang representasi matematik siswa SD dalam menyelesaikan masalah matematika kontekstual. Hasil penelitian tersebut menyimpulkan bahwa dalam menyelesaikan masalah kontekstual, sebagian besar siswa menggunakan tabel dan gambar dan sebagain kecil menggunakan representasi pernyataan tertulis, simbol, dan konjektur. Disamping itu, hanya sebagian kecil siswa yang merepresentasikan soal dalam bentuk model matematika. Selain itu, masih banyak lagi penelitian-penelitian yang berkaitan dengan matematika kontekstual, yaitu: penelitian Lestari dan Madio (2013), penelitian Maryati (2016), penelitian Nursyahidah dkk. (2020), dan penelitian lainnya.

Berdasarkan uraian tersebut maka penelitian ini mengarah pada kebaruan dan orisinalitas yang berkaitan dengan kemampuan pemodelan matematis dan soal matematika konteksual. Sehingga penelitian ini bertujuan untuk mendeskripsikan kemampuan pemodelan matematika siswa dalam menyelesaikan soal matematika kontekstual.

\section{Metode}

Penelitian ini adalah penelitian kualitatif yang bertujuan untuk mendeskripsikan dan menganalisis kemampuan pemodelan matematis siswa dalam menyelesaikan soal matematika kontekstual. Penelitian kualitatif merupakan penelitian yang dilakukan dengan kondisi yang alamiah (Siyoto \& Sodik, 2015). Subjek penelitian ini adalah siswa SMP di Depok, Jawa Barat sebanyak 6 siswa yang terdiri dari kelompok siswa dengan kemampuan matematika tinggi, sedang, rendah.

Kemampuan siswa dalam membuat pemodelan matematis dalam menyelesaikan soal matematika kontekstual diteliti serta diamati secara alamiah (apa adanya) berdasarkan tes tertulis dan hasil wawancara kemudian akan dianalisis secara mendalam. Masalah penelitian dibatasi pada kemampuan pemodelan matematis siswa pada materi bangun ruang sisi datar, data yang telah 
diperoleh dikumpulkan, dirangkum, diperiksa kebenarannya kemudian diinterpretasikan sehingga menjadi suatu informasi yang bermakna. Langkahlangkah pada penelitian ini yaitu: (1) memberikan tes kemampuan pemodelan matematis pada siswa berupa soal uraian sebanyak 5 soal; (2) melakukan analisis terhadap hasil pekerjaan siswa pada tes kemampuan pemodelan matematis; (3) melakukan wawancara berdasarkan hasil pekerjaan siswa (4) menganalisis hasil pekerjaan siswa pada tes kemampuan pemodelan matematis dan hasil wawancara terhadap siswa.

Instrumen dalam penelitian ini yaitu tes kemampuan pemodelan matematis untuk mengungkap sejauhmana siswa menggunakan pemodelan matematis untuk menyelesaikan soal matematika kontekstual. Soal kemampuan pemodelan matematika yang diberikan.

Andi memiliki kardus yang berukuran $50 \times 20 \times 30 \mathrm{~cm}$. Kardus tersebut digunakan untul menyimpan mainan berbentuk kotak yang setiap rusuknya memiliki ukuran $10 \mathrm{~cm}$.

a) Gambarlah kardus yang didalamnya berisi mainan sehingga mainan tersebu memenuhi kardus (Gunakan skala 1:10)

b) Dapatkah Kamu membuat kaitan antara volume kardus dan volume mainan

Gambar 1. Soal kemampuan pemodelan matematika

\section{Hasil dan Pembahasan}

Berdasarkan hasil penelitian yang telah dilakukan terdapat beberapa temuan penelitian terkait kemampuan pemodelan mtematis siswa. Kemampuan pemodelan matematis siswa memiliki beberapa indikator menurut Blum dan Kaiser (Supriadi dkk., 2014) yaitu structuring, mathematization, solving, interpreting, dan validating. Pada pembahasan ini akan di analisis beberapa temuan penelitian berdasarkan jawaban yang diberikan oleh subjek. Dari hasil analisis tersebut ditemukan bahwa beberapa siswa masih kesulitan untuk memahami pertanyaan dalam bentuk soal cerita, artinya kemampuan siswa pada indikator structuring masih belum baik sehingga yang akan dibahas pada pembahasan hanya indikator stucturing yaitu melakukan indentifikasi pada masalah nyata.

Pada indikator structuring subjek diminta untuk mengidentifikasi sebuah kardus berbentuk balok dengan ukuran yang telah ditentukan terisi penuh mainan berbentuk kubus dengan ukuran yang telah ditentukan pula. Gambar 2 di bawah ini adalah hasil pengerjaan subjek dengan kemampuan matematika rendah diberikan kode S3.

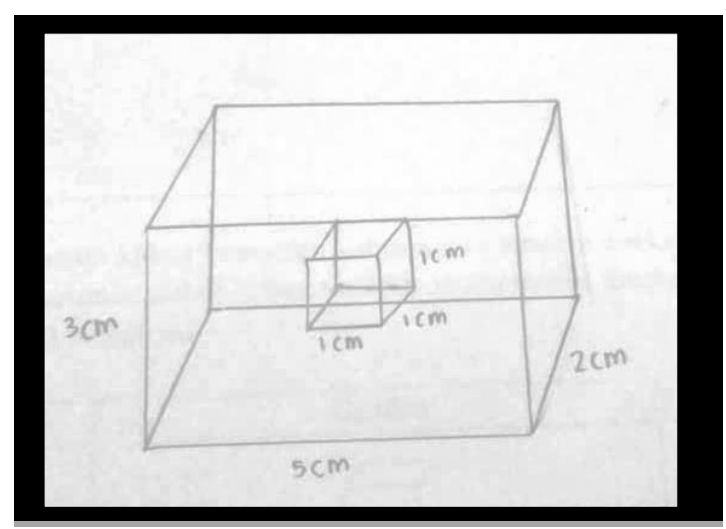

Gambar 2. Jawaban Subjek S3 
Subjek S3 menggambar kardus dan mainan dengan ukuran yang tepat sesuai dengan pedoman pada soal namun subjek kurang tepat dalam melakukan structuring atau identifikasi terhadap masalah nyata. Data hasil wawancara subjek S3 menyebutkan bahwa subjek kurang memahami soal yang diberikan sehingga subjek hanya menggambar satu mainan dalam kardus tersebut. Proses structuring merupakan proses transisi antara masalah pada dunia nyata dan masalah matematika. Kesalahan subjek dalam melakukan identifikasi terhadap masalah nyata telah dikemukakan oleh Pape \& Wang (2003) dalam penelitiannya yang menyatakan bahwa kesulitan yang banyak dialami siswa dalam memecahkan masalah adalah memahami serta menafsirkan masalah ke dalam bentuk variable atau bentuk matematika lainnya. Hal ini menyebabkan ketika siswa mentransformasikan masalah ke dalam bentuk matematika akan mengalamai kesalahan atau mis konsepsi. Menurut Wickelgren (L. M. Fauzi, 2018) dalam semua masalah formal ada tiga jenis informasi yang perlu diperhatikan, diantaranya adalah informasi tentang masalah yang diberikan, informasi tentang operasi yang dapat digunakan untuk menyelesaikan satu atau lebih variabel baru, dan informasi mengenai penyelesaian seperti apa yang akan dituju. Informasi-informasi inilah yang akan membantu siswa dalam menentukan langkah penyelesaian masalah.
Temuan lainnya terlihat pada Gambar 3 yang merupakan hasil pengerjaan subjek dengan kemampuan matematis sedang yang diberi kode $\mathrm{S} 2$.

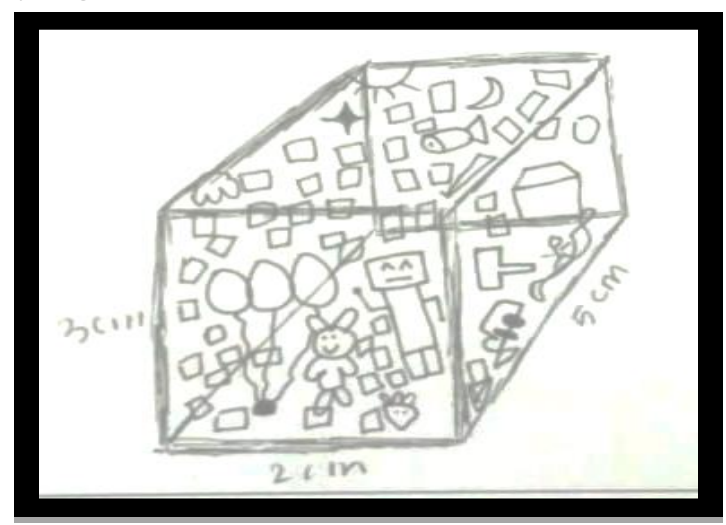

Gambar 3. Jawaban Subjek S2

Subjek S2 menggambar sebuah kardus yag berisi mainan yg memenuhi kardus. Ini menunjukan ketidaktelitian subjek S2 dalam membaca dan memahami soal. Berdasarkan wawancara yang dilakukan, subjek memberikan keterangan bahwa subjek tidak tahu bahwa mainan yang diminta berbentuk kubus sehingga subjek S2 hanya menggambar mainan yang memenuhi kardus. Ketidaktelitian subjek dalam membaca dan memahami bacaan menyebabkan subjek kurang tepat dalam memahami masalah. Dalam hal ini subjek melakukan kesalahan konseptual. Kesalahan konseptual yaitu kesalahan dalam mengartikan fakta konsep dan suatu prinsip (kastolan, dalam Natsir dkk., 2016). Dalam menyusun suatu pemodelan matematis diperlukan keterampilan untuk mentransformasi masalah nyata ke dalam masalah matematika secara tepat agar pemodelan matematika yang dibuat dapat 
merepresentasikan masalah secara benar. Hal ini akan berdampak pada pengambilan keputusan yang diambil. Apabila dalam menyusun pemodelan matematis tidak sesuai dengan masalah yang dihadapi maka keputusan ataupun kesimpulan yang akan diambilpun menjadi tidak tepat. Dahlan \& Juandi (2011) menyatakan bahwa dalam memformulasikan masalah menjadi model matematika, siswa harus mempunyai keterampilan representasi ganda untuk mengartikan masalah yang sama dalam bentuk atau sudut pandang yang berbeda.

Selanjutnya adalah hasil pengerjaan subjek dengan kemampuan matematis tinggi yang diberi kode S1.

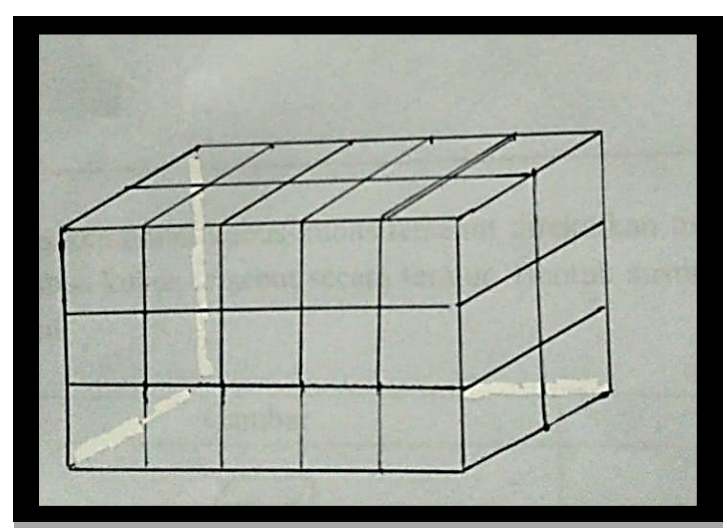

Gambar 4. Jawaban Subjek S1

Pemodelan matematis yang dibuat oleh subjek S1 sudah tepat. Ukuran kardus yang dibuat juga sudah sesuai dengan soal yang diminta. Pemahaman subjek S1 dalam mentransformasikan masalah ke dalam model matematis juga sudah baik. Dalam menyelesaikan suatu bentuk soal cerita, hal yang paling mendasar yang harus dilakukan adalah membaca soal dengan teliti sehingga tidak menimbulkan kesalahan konsep yang akan berakibat pada kesalahan dalam membangun model matematika. Ketika siswa tidak memahami masalah yang benar, kemudian membuat model matematika yg tidak tepat sehingga berakhir dengan pengambilsn kesimpulan yang tidak tepat. Sebaliknya, jika subjek S1 mampu memahami masalah dengan benar maka akan tepat pula dalam mengambil keputusan. Hal ini terlihat dari hasil jawaban S1 di bawah ini.

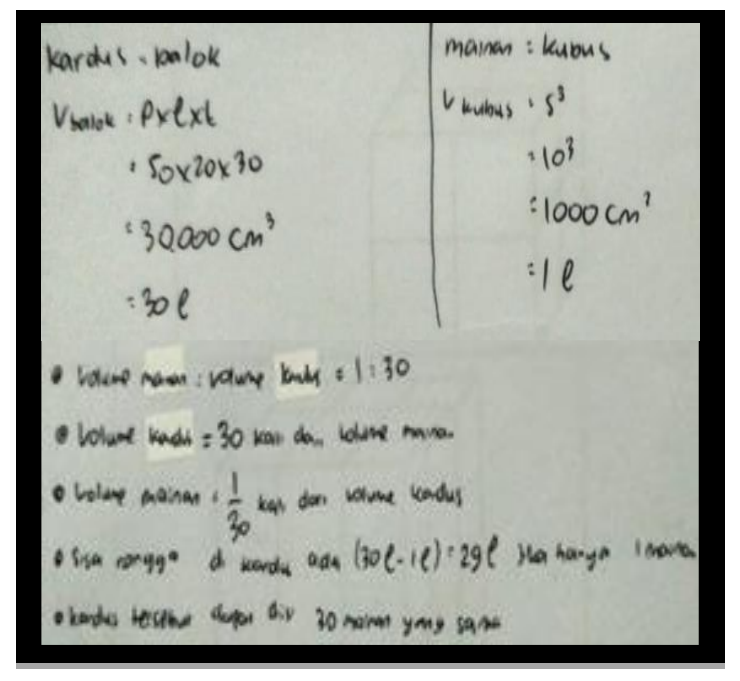

Gambar 5. Jawaban Subjek S1

Ketika subjek S1 diminta untuk membuat kaitan antara volume kardus dan mainan, subjek S1 yang tepat dalam membuat pemodelan matematis akan lebih mudah membuat kesimpulan tentang kaitan antara volume kardus dan volume mainan. Beberapa kesimpulan yang dikemukakan subjek S1 yaitu perbandingan volume mainan dan volume 
kardus adalah 1 : 30. Jawaban lainnya yang dikemukakan adalah kardus tersebut dapat menampung mainan sebanyak 30 buah. Hasil ini memberikan gambaran bahwa subjek S1 dapat mengaitkan kesimpulan ke dalam matematika maupun mentransformasikan kesimpulan ke masalah nyata. Variasi jawaban yang diberikan subjek subjek S1 menandakan bahwa subjek S1 paham dengan model matematika yang telah dibuat. Hal ini sejalan dengan pendapat maab (Wijaya, A. 2012) bahwa pemodelan membantu siswa dalam memahami dan menguasai konsep matematika dengan lebih mudah. Penyebab dari hal tersebut yaitu karena pemodelan matematika merupaka proses menggunakan kekuatan matematika untuk menyelesaikan masalah nyata (Bahmaei, 2011).

Di bawah ini merupakan jawaban dari subjek S2 dengan kemampuan matematika sedang.

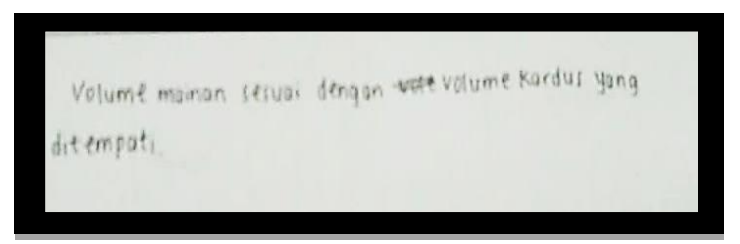

Gambar 6. Jawaban Subjek S2

Gambar 6 memperlihatkan ketidakmampuan subjek S2 dalam membuat kesimpulan karena pemodelan matematis yang dibuat tidak mampu memberikan gambaran tentang masalah nyata secara benar. Hasil wawancara yang dilakukan memberikan informasi bahwa siswa tidak paham dari awal ketika diminta untuk membuat kardus yang berisi penuh mainan berbentuk kubus, sehingga dalam membuat kesimpulannya pun siswa tidak mengerti bagaimana cara menyimpulkan masalah yang tidak ia pahami. Fungsi dari pemodelan matematis yaitu menyederhanakan masalah dengan memilih hal-hal yang dianggap penting dan menyingkirkan hal yang dianggap tidak membantu dalam menyelesaikan masalah agar lebih mudah dipahami, memudahkan dalam menyelesaikan masalah dengan menggunakan matematika secara formal, dan tepat dalam mengambil suatu kesimpulan dari hasil penyelesaian dengan menggunakan proses matematika formal. Sehingga dari beberapa temuan diatas dapat kita katakan bahwa kemampuan pemodelan matematis merupakan kemampuan yang sangat penting dalam matematika.

Kemampuan pemodelan matematika dapat membantu siswa dalam memecahakan masalah matematis. Oleh karena itu pemecahan masalah dan pemodelan matematika merupakan hal yang saling berkaitan. Setiap siswa membuat model, kreasi dan memberikan konstribusi dalam pembelajaran dengan memunculkan strategi-strategi pemecahan yang berbeda (Mulyati, 2016). Pengetahuan awal yang dimiliki siswa berpengaruh terhadap model yang dibuat dalam menyelesaikan masalah, sehingga semakin banyak pengetahuan awal yang dimiliki siswa semakin beragam pula 
model matematis yang dapat disajikan oleh siswa tersebut dalam menyelesaikan masalah.

\section{Penutup}

Berdasarkan penelitian yang telah dilakukan, peneliti menarik beberapa kesimpulan yaitu (1) kemampuan pemodelan matematis siswa beragam, tidak bergantung pada kemampuan matematika siswa tinggi, sedang, rendah. $\mathrm{Hal}$ ini terlihat dari hasil kemampuan pemodelan matematis siswa tinggi tidak lebih baik dari kemampuan siswa sedang maupun rendah. (2) Sebagian besar siswa mampu membuat pemodelan matematika, namun masih ada siswa yang tidak membuat pemodelan matematika karena tidak memahami soal yang diberikan. (3) Bentuk pemodelan gambar yang dibuat oleh siswa masih beragam, tetapi sebagian besar masih kurang tepat dalam membuat pemodelan gambar sesuai dengan permasalahan yang diberikan.

Sesuai dengan kesimpulan yang telah disampaikan di awal maka peneliti memberikan beberapa rekomendasi terkait kemampuan pemodelan matematika. (1) kemampuan pemodelan masalah matematis merupakan kemampuan yang dibutuhkan dalam memecahkan masalah sehingga kemampuan ini penting untuk dimiliki oleh siswa, oleh karena itu pembelajaran yang melibatkan pemodelan matematis dirasa penting diajarkan kepada siswa agar siswa bisa menggunakan matematika dalam konteks kehidupan. (2) Pemberian soalsoal dalam bentuk masalah nyata diperlukan agar siswa dapat mampu mentransformasikan masalah tersebut dalam konteks matematika.

\section{UCAPAN TERIMA KASIH}

Kami mengucapkan terima kasih kepada Lembaga Penelitian UHAMKA yang telah mendukung agar penelitian ini terlaksana dengan baik. Selain itu terima kasih kepada kepala sekolah, guru, maupun siswa di sekolah tempat penelitian Kami yang telah terlibat dan memfasilitasi pelaksanaan penelitian ini.

\section{Daftar Pustaka}

Afriansyah, E. A. (2015). Students' Misconception in Decimal Numbers. International Seminar on Teacher Education 1st ISTE UIN Suska.

Afriansyah, E. A., Herman, T., Turmudi, T., \& Dahlan, J. A. (2020). Mendesain Soal Berbasis Masalah untuk Kemampuan Berpikir Kritis Matematis Calon Guru. Mosharafa: Jurnal Pendidikan Matematika, 9(2), 239-250.

Agnesti, Y., \& Amelia, R. (2020). Penerapan Pendekatan Kontekstual dalam Menyelesaikan Soal Cerita pada Materi Perbandingan dan Skala terhadap Siswa SMP.Mosharafa: Jurnal Pendidikan Matematika,9(2), 347-358.

Amala, M. A \& Ekawati, R. (2016). Profil Proses Matematisasi Horizontal dan Vertikal Siswa SMP dalam Menyelesaikan Masalah Kontekstual Pecahan Ditinjau dari Kemampuan 
Matematika. MATHEdunesa Jurnal Ilmiah Pendidikan Matematika, 3(5), 301-309.

Bahmaei, F. (2011). Mathematical modelling in primary school, advantages and challenges. Journal of Mathematical Modelling and Application, 1(9), 3-13.

Brinus, K. S. W., Makur, A. P., \& Nendi, F. (2019). Pengaruh model pembelajaran kontekstual terhadap pemahaman konsep matematika siswa smp. Mosharafa: Jurnal Pendidikan Matematika, 8(2), 261-272.

Dahlan, J. A., \& Juandi, D. (2011). Analisis Representasi Matematik Siswa Sekolah Dasar Dalam Penyelesaian Masalah Matematika Kontekstual. Jurnal Pengajaran Matematika Dan IImu Pengetahuan Alam, 16(1), 128. https://doi.org/10.18269/jpmipa.v16i 1.273

Dwiwansyah Musa, L. A. (2017). Meningkatkan Hasil Belajar Matematika Melalui Pendekatan Matematika Realistik. Kelola: Journal of Islamic Education Management, 2(1), $\quad$ 78-91. https://doi.org/10.24256/kelola.v2i1.4 45

Edo, S. I., \& Tasik, W. F. (2019). Design research on applied Realistic Mathematics Education (RME) approach in teaching math for vocational college. Jurnal Pendidikan Vokasi, 9(3), 294-306. https://doi.org/10.21831/jpv.v9i3.278 39

Fauzi, A., \& Susilo, M. B. (2017). Penerapan Buku Ajar Matematika Realistik Untuk Meningkatkan Aktivitas dan Hasil Belajar Siswa. 163-168.
Fauzi, L. M. (2018). Identifikasi Kesulitan Dalam Memecahkan Masalah Matematika. JIPMat, 3(1), 21-28. https://doi.org/10.26877/jipmat.v3i1. 2286

Herawati, L., \& Nurhayati, E. (2019). Eksperimentasi Model Pembelajaran Cooperative Script untuk Melatih Kecakapan Akademik Siswa. Mosharafa: Jurnal Pendidikan Matematika, 8(1), 131-142.

Hernawati, D. (2012). Aplikasi Matematika dalam Pengaturan Berat Badan dengan Menghitung Kalori dan Menggunakan Sistem Body Mass Index (Bmi). Mosharafa: Jurnal Pendidikan Matematika, 1(2), 63-66.

Karabork, M. A., \& Durmus, S. (2020). Effects of Redesigned Model Eliciting Activities on Seventh Grade Students' Mathematics Success and Students ' Views about These Activities. 3(2), 3445.

Lestari, N., \& Madio, S. S. (2013). Perbedaan Prestasi Belajar Matematika Siswa antara yang Mendapatkan Model Pembelajaran Kooperatif Tipe Jigsaw dan Kontekstual. Mosharafa: Jurnal Pendidikan Matematika,2(3), 169178.

Lisnani, L. (2019). Pengaruh Penggunaan Konteks Daun terhadap Hasil Belajar Siswa. Mosharafa: Jurnal Pendidikan Matematika, 8(3), 423-434.

Maryati, I. (2016). Upaya Meningkatkan Kemampuan Pemecahan Masalah Matematik Siswa Sekolah Menengah Pertama Melalui Pembelajaran Kontekstual. Mosharafa: Jurnal Pendidikan Matematika, 5(1), 1-9.

Mulyati, T. (2016). Kemampuan 
Pemecahan Masalah Matematis Siswa Sekolah Dasar (Mathematical Problem Solving Ability of Elementary School Students). EDUHUMANIORA: Jurnal Pendidikan Dasar, 3(2), 1-20.

Muzaki, A., \& Masjudin, M. (2019). Analisis Kemampuan Literasi Matematis Siswa. Mosharafa: Jurnal Pendidikan Matematika, 8(3), 493-502.

Nanang, N. (2012). Meningkatkan Kemampuan Siswa dalam Pemecahan Masalah Matematik melalui Pendekatan Metakognitif. Mosharafa: Jurnal Pendidikan Matematika, 1(1), 1-8.

Nursyahidah, F., Saputro, B. A., Albab, I. U., \& Aisyah, F. (2020). Pengembangan learning trajectory-based instruction materi kerucut menggunakan konteks megono gunungan. Mosharafa: Jurnal Pendidikan Matematika, 9(1), 47-58.

Nursyarifah, N., Suryana, Y., Abdul, D., \& Lidinillah, M. (2017). Penggunaan Pemodelan Matematik Untuk Meningkatkan Kemampuan Pemecahan Masalah Aritmatika Sosial Siswa Sekolah Dasar. PEDADIDAKTIKA: Jurnal IImiah Pendidikan Guru Sekolah Dasar, 3(1), 138-149.

Nuryadi. (2014). Keefektifan Pendekatan

CTL dan PPM Pembelajaran Matematika Metode GTG Ditinjau Keaktifan dan Prestasi Siswa Effectiveness of CTL Approach and PPM with GTG Method on Mathematics Teaching in Terms of Learning Activeness and Achievement of the Students. PYTHAGORAS: Jurnal Pendidikan Matematika, 9(1), 22-30. Nuryadi, A., Santoso, B., \& Indaryanti, I. (2018). Kemampuan Pemodelan Matematika Siswa Dengan Strategi
Scaffolding With A Solution Plan Pada Materi Trigonometri Di Kelas X SMAN 2 Palembang. Jurnal Gantang, 3(2), 73-81.

https://doi.org/10.31629/jg.v3i2.468

Pape, S. J., \& Wang, C. (2003). Middle school children's strategic behavior: Classification and relation to academic achievement and mathematical problem solving. Instructional Science, 31(6), 419-449. https://doi.org/10.1023/A:102571070 7285

Pitriani. (2016). Kemampuan Pemodelan Matematika dalam Realistic Mathematics Education (RME). JESMAT, 9(2), 10. https://doi.org/10.5151/cidi2017-060

Puspitasari, N. (2012). Hidup Manusia di Dunia Konvergen ke $\mathrm{F} \quad(\mathrm{X})=$ 0. Mosharafa: Jurnal Pendidikan Matematika, 1(2), 59-62.

Rachma, Y. Y., Setyadi, D., \& Mampouw, H. L. (2020). Pengembangan Mobile Learning Barusikung Berbasis Android pada Materi Bangun Ruang Sisi Lengkung. Mosharafa: Jurnal Pendidikan Matematika,9(3), 475486.

Lisnani, L. (2019). Pengaruh Penggunaan Konteks Daun terhadap Hasil Belajar Siswa. Mosharafa: Jurnal Pendidikan Matematika, 8(3), 423-434.

Rahayu, D. V. (2012). Meningkatkan Kemampuan Pemecahan Masalah Matematis Siswa melalui Pendekatan Pembelajaran

Kontekstual. Mosharafa: Jurnal Pendidikan Matematika, 1(2), 73-82.

Rahmawati, F. (2013). Pengaruh Pendekatan Pendidikan Realistik Matematika dalam Meningkatkan 
Kemampuan Komunikasi Matematis Siswa Sekolah Dasar. Prosiding SEMIRATA 2013, 1(1), 225-238. http://jurnal.fmipa.unila.ac.id/index.p $\mathrm{hp} /$ semirata/article/view/882

Rizki, M. (2018). Profil Pemecahan Masalah Kontekstual Matematika oleh Siswa Kelompok Dasar. Jurnal Dinamika Penelitian: Media Komunikasi Sosial Keagamaan, 18(02), 271-286. https://doi.org/10.1017/CB09781107 415324.004

Sari, H. M., \& Afriansyah, E. A. (2020). Analisis Miskonsepsi Siswa SMP pada Materi Operasi Hitung Bentuk Aljabar. Mosharafa: Jurnal Pendidikan Matematika, 9(3), 439-450.

Suharyono, E., \& Rosnawati, R. (2020). Analisis Buku Teks Pelajaran Matematika SMP ditinjau dari Literasi Matematika. Mosharafa: Jurnal Pendidikan Matematika,9(3), 451462.

Sumarmo, U., Hidayat, W., Zukarnaen, R., Hamidah, M., \& Sariningsih, R. (2012). Kemampuan Dan Disposisi Berpikir Logis, Kritis, Dan Kreatif Matematik (Eksperimen terhadap Siswa SMA Menggunakan Pembelajaran Berbasis Masalah dan Strategi Think-TalkWrite). Jurnal Pengajaran Matematika Dan IImu Pengetahuan Alam, 17(1), 17-33.

https://doi.org/10.18269/jpmipa.v17i 1.228

Supriadi, Suryadi, D., Sumarmo, U., \& Rakhmat, C. (2014). Developing Mathematical Modeling Ability Students Elementary School Teacher Education Through Ethnomathematics-Based Contextual
Learning. International Journal of Education and Research, 2(8), 439452.

Yanuarto, W. N., Matematika, P., Muhammadiyah, U., Jl, P., Dukuh, R., \& Box, P. O. (2014). Pengembangan Model Pembelajaran Kontekstual Matematika di SMP Kelas IX yang Menekankan Religiusitas Peserta Didik. Pythagoras: Jurnal Pendidikan Matematika, 9(2), 186-195. https://doi.org/10.21831/pg.v9i2.907

\section{9}

\section{Riwayat Hidup PenUlis}

\section{Hikmatul Khusna, M.Pd.}

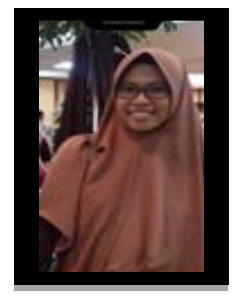

Lahir di Jakarta, 1 April 1991. Dosen pendidikan matematika di Universitas Muhammadiyah Prof Dr HAMKA. Studi S1 Pendidikan Matematika, Universitas Muhammadiyah Prof Dr HAMKA, Jakarta, lulus tahun 2013; S2 Pendidikan Matematika, Universitas Pendidikan Indonesia, Bandung, lulus tahun 2015.

\section{Syafika Ulfah, S.Pd., M.Sc.}

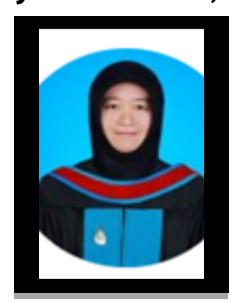

Lahir di Jakarta, 15 Juli 1990. Dosen pendidikan matematika di Universitas Muhammadiyah Prof Dr HAMKA. Studi S1 Pendidikan Matematika, Universitas Muhammadiyah Prof Dr HAMKA, Jakarta, lulus tahun 2012; S2 Applied Mathematics, Prince of Songkla University, Pattani, Thailand, lulus tahun 2016. 